\title{
Mass mortality of gorgonians due to a Cyphoma gibbosum (Linnaeus) population outbreak at Mona Island, Puerto Rico
}

Received: 24 January 2010/Accepted: 6 February 2010/Published online: 8 March 2010

(C) Springer-Verlag 2010
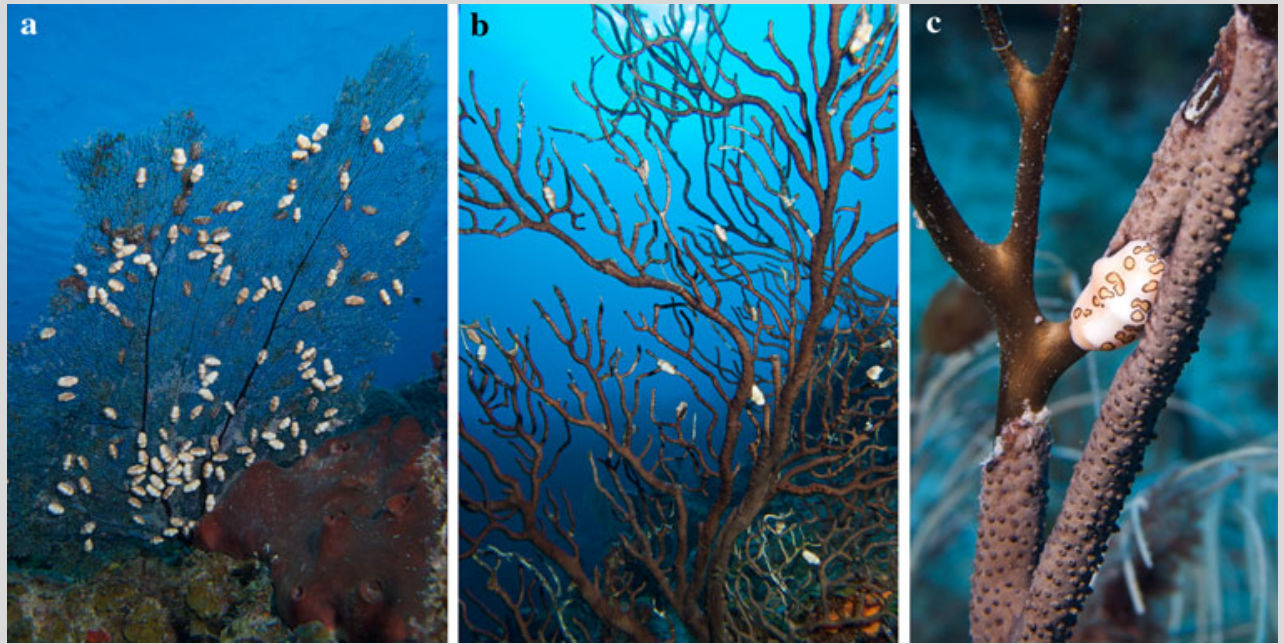

Fig. 1 Gorgonians with infestations of Cyphoma gibbosum at Mona Island. a Completely predated Gorgonia ventalina, b partially predated Iciligorgia schrammi, and c close up of predation effects on Pseudoplexaura sp.

Although the impact of predation by Cyphoma gibbosum has been reported as minimal on gorgonian survivorship (Yoshioka and Yoshioka 1991), during population outbreaks, their effects may influence the abundance and spatial distribution of gorgonians on coral reefs. In the Caribbean, localized C. gibbosum outbreaks have been documented since the 1980s (Williams and Bunkley-Williams 2000). At the remote coral reefs of Mona Island, Puerto Rico, an outbreak of $C$. gibbosum has decimated over $90 \%$ (based on roving surveys) of the shallow water gorgonians (Fig. 1a) since 2008. Although at first, only a few individual gorgonian colonies were affected by large numbers of snails in a localized area of the southern coast, a recent survey confirms the infestation is widespread throughout the island's coral reefs and gorgonian mortality is massive.

All gorgonians are colonized by extremely high numbers of $C$. gibbosum including Eunicea sp., Gorgonia ventalina, Plexaura flexuosa, Plexaura sp., Pseudoplexaura sp., Pseudopterogorgia americana, Pterogorgia sp., and the previously unreported Iciligorgia schrammi (Fig. 1b). Colonies with aggregations of $C$. gibbosum were observed to depths of $40 \mathrm{~m}$ and were more frequent on G. ventalina. The average number of snails per colony was 34.4 at four shelf-break sites, and the maximum number was of 190 snails per colony on G. ventalina. Predation completely denudes live tissue (Fig. 1c) sloughing the sclera layer and leaving the proteinaceous axes exposed to fouling by cyanobacteria and algae. Solitary Hermodice carunculata were observed on a few heavily infested colonies.

\section{References}

Williams EH, Bunkley-Williams L (2000) Marine major ecological disturbances of the Caribbean. Infect Dis Rev 2:110-127 Yoshioka PM, Yoshioka BB (1991) A comparison of the survivorship and growth of shallow-water gorgonian species of Puerto Rico. Mar Ecol Prog Ser 69:253-260

\section{T. Schärer $(\bowtie)$}

Sea Grant College Program, University of Puerto Rico, Call Box 9000, Mayagüez 00681-9000, Puerto Rico e-mail: m_scharer@hotmail.com

M. I. Nemeth

Department of Marine Sciences, University of Puerto Rico, Call Box 9000, Mayagüez 00681-9000, Puerto Rico

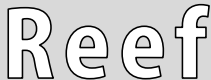

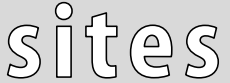
Coral Reefs (2010) 29:533 DOI $10.1007 / \mathrm{s} 00338-010-0598-1$ 